\title{
Attitude of Male and Female Students Towards Computer Assisted Language Learning at Intermediate Level
}

\author{
Muhammad Arfan Lodhi ${ }^{1}$, Ayesha Fatima ${ }^{2}$, Farzana Ismail ${ }^{3}$, Nadia Amin ${ }^{4}$, Faiza Khalid ${ }^{5}$ \& Ayesha Siddiqa ${ }^{2}$ \\ ${ }^{1}$ Higher Education Department Collegiate Wing, Punjab \\ ${ }^{2}$ NCBA\&E University, Lahore \\ ${ }^{3}$ The Islamia University Bahawalpur \\ ${ }^{4}$ APSACS Rahim Yar Khan \\ ${ }^{5}$ District Education Department Rahim Yar Khan \\ Correspondence: Muhammad Arfan Lodhi, Higher Education Department Collegiate Wing, Punjab Pakistan.
}

Received: December 18, 2018 Accepted: February 8, 2019 Online Published: February 10, 2019

doi: 10.5539/elt.v12n3p108 URL: https://doi.org/10.5539/elt.v12n3p108

\begin{abstract}
Today's world is the era of technology and it is playing a dominant role in the field of education. The current research work is quantitative in nature. It aims to investigate students' attitudes, their interests and difficulties regarding the concept of computer assisted language learning at intermediate level. A self reported questionnaire (SRQ) was designed and administered to obtain the objectives of the current study. The sampling statistic comprised of 300 students with equal gender from public and private colleges. The collected data was statistically analyzed by running descriptive statistic technique. The findings revealed that male students had more positive attitude towards CALL as compared to their female counterparts. However, it was also revealed that male students found CALL interesting for the development of language proficiency while female students faced more difficulties in using computer technology for English Language learning. The results provide ideas, paths and suggestions to the future researchers to undergo further investigations in developing computer mediating language learning programs for the benefits of learners and learning.
\end{abstract}

Keywords: computer assisted language learning, English proficiency, learners' attitude, gender differences

\section{Introduction}

Computer mediated technology has become one of the most important mean and aspect of successful learning. The development and progress in technology change the attitudes and the preferences of students toward learning. Computer has become an important tool to attain success, and this technology is being used in many fields especially in the field of education. Computer assisted language learning (CALL) is fundamental part of English teaching methodology and it is very well acknowledged mean to attain learning objectives. Computers provide many opportunities of exchanging ideas and information at both national and international level. Before this technology students were not able to learn language easily and they had to face many hurdles and difficulties. The classical and traditional methods used by the old teachers couldn't help them to learn foreign language effectively; the old teaching methods couldn't fulfill the requirements of learning and learners. But now the advanced and progressive technology of computer has motivated the learners to learn language effectively. It became the valuable tool of learning for modern students. Through computer networks students can gain knowledge about the language and the culture of its speakers (Higgins \& Chris, 1993).

The technology of computer was introduced in the field of language learning in 1960s. The early 1980s observed the tendency that students had become aware with the benefits of CALL, since then it has been widely used in practice throughout Europe and America. Many scholars and the teachers found out that CALL approach comfortably met with the learners' requirements and their need of learning. CALL had a great contribution in increasing the language learning capacity and tendency of students, and it positively modified their interest, skills and abilities. Many schools, colleges and universities carried out the technology of CALL in their instructional plans. Today the use of CALL has become so much advanced that many educational institutions have made it compulsory to use computer mediated technology for teaching, mentoring, examining, and evaluating purposes. 


\subsection{Historical Background of English}

In the $19^{\text {th }}$ century, the industrial revolution opened the way for Britain's economic power and as a result English globally spread all around the world. After the Second World War, the dominant political and military power of US has given English the status of standard language for international communication. And in the $20^{\text {th }}$ century, the progress of technology plays an important role in the spread of English all over the world. Today English is recognized as an important and globalized language as it has become the official language of the professional and technical world (Schutz, 2005). In the globally contracted world, English is considered as a medium of instructions in all fields especially in the field of education. Today most of the countries are utilizing English language in their institutions and educational curriculum. English has a global significance as it is used in research, trade, technology, education and so on. Due to this the United Nations has given English a special status (Al-Hajailan, 2003). The learning and usage of this global language has shifted the gear of its pedagogical strategies. Teachers and institutions have started using innovative English teaching methodologies like Task based language teaching, flipped teaching, and blended learning and teaching programs etc. CALL is one of the mostly used English teaching strategies as it provides real life innovative and interesting authentic material for teaching and learning purpose.

\subsection{Objectives of the Study}

The purpose of the current work was to obtain the following objectives:

1) To examine the students' attitude towards computer assisted language learning

2) To identify if students find CALL functional and interesting in developing their language proficiency skills

3) To explore the difficulties learners may face during using computer mediating technology for learning English language

\section{Literature Review}

The use of technology is playing an important role in the learning and teaching of English proficiency skills. The utilization of information technology has changed the shape of traditional classrooms and libraries. During this century the technology is so progressive and advanced that for the purpose of knowledge many other technologies came into existence such as sound and video data and multimedia programs (Mishra \& Sharma, 2005). In 1980s, computer was considered as an important educational tool for the purpose of learning and teaching the language of English. In 2000, many researchers have acknowledged the power and the future of CALL and they recognized the importance of computers in developing language proficiency among learners. The $21^{\text {st }}$ century is known as technical and digital age, as technology has a great impact in our lives especially towards the area of education (Abdullah, 2005). Due to the progressive and vast technology the learners and the teachers are trying to enrich themselves by the benefits of computer mediated technology. The advanced technology especially computers offer teachers and students to learn and teach English language effectively through the CALL. CALL is the useful approach of learning and teaching the foreign language (Vrasidas, Georgeous, \& Papanastasiou, 2007). Computers give the opportunity to the students to use the different programs of learning English as a second or foreign language either in the group or individually. It provides flexibility in learning and enables the learners to learn the language according to their desires and needs. It gives the chance to learner to repeat and listen as much as he/she wants without the control of teacher. In this type of learning environment both teacher and learner feel at ease, and it consequently enables the learners to communicate in target language comfortably. The use of computers in the system of education provides many opportunities to both teacher and the students as they can get many teaching and learning benefits from computer based learning. In student centered classroom, the students take the responsibility for their own learning. CALL provides many resources to the students to develop their vocabulary, grammar, reading, writing, listening and speaking skills. Due to CALL, the role of the student is converted from "being taught" to "learning" (Jaber, 1997). It strengthens the learners' autonomous concept of learning.

\subsection{CALL and Teaching-Learning Concept}

Since 1990 CALL is accepted globally. The technology of CALL is utilized in the achievement of second language (Hacken, 2003). The term of CALL is driven from CAI (Computer Accelerated Instruction), a tool that was considered as a first support for the teachers. The focal point of the CALL is student centered learning and it motivates the learners to achieve their task that is self-learning. Computer assisted language learning was first introduced in the beginning of 1960s. It is firstly seen as an aid for teachers. Many teachers and the research scholars considered that CALL encounters the demands of language learning and because of this many educational institutions carried CALL in their language learning goals. CALL played an important role in the 
motivation of learners, and the achievement of students' goal in the target language. CALL is not a method; it is a tool which helps the students in the language learning. According to Levy CALL is the search for and study of applications of the computer in language teaching and learning (Levy, 1997). CALL is also helpful in reinforcing the students that what they had learned in the classroom. The worthy use of CALL was started in the 1960s. Since then different softwares of CALL have been introduced in the field of teaching (Vincent \& Hah, 1996).

\subsection{CALL in Pakistan}

English language plays two important roles in Pakistan. Its first role is that it is used as an official language in Pakistani offices and its second role is that it is used as a medium of instructions in higher institutions and private schools. In Pakistani institutions English is taught as a compulsory subject. It is a source of getting well and high education and also a source of livelihood. Many scholars define English as an instrumental function. These two roles of English are linked with technology i.e. CALL.

The use of CALL gives confidence and encouragement to the students to learn by their own. According to Javid \& Farooq "This global trend has influenced all walks of life and the realm of English language teaching is no exception" (Javid \& Farooq, 2015, p. 38). Today, most of the Pakistani educational institutions are enriched with technology. Teachers and the students both use technology in the teaching-learning process, for example, teachers use E- mails to receive or send the papers while students use internet to gain knowledge or to learn about something related to their subjects. However, the technology of CALL, though not new in Pakistan, could not establish well in the field of English learning and teaching.

In 1999 the Government of Pakistan conducted a study to highlight that in 1985 forty- eight main-frame computers and fifty mini-computers were introduced in public sector and eleven main-frame computers and fifty-nine mini-computers were introduced in private sectors. These computers were also utilized in Pakistani educational fields. The universities of Pakistan also developed computer departments in their campuses in order to enhance the learning and the skills of their students. It was a major drawback that in 1980s the use of micro-computers played an important role in an educational system at a worldwide level but in Pakistan educational system didn't include the use of computer for educational plans. In 1992, the Government of Pakistan gave importance to the use of computer in educational field that is reflected in the following words:

Computer based education will be utilized as a necessary element in teachers workshops and also in the administration of education. And in the teaching-learning process computer aided instruction will be the important tool (Ministry of Education, 1992).

National Educational Policy, as discussed in Ministry of education (1998-2010), was proved fruitful for the implementation of CALL in the learning of second language in Pakistan. Kronstadt (2004) demonstrated that Government of Pakistan announced in July, 2004 that the computers would be provided in public schools of Pakistan that was why, in 2005, Higher Education Commission (HEC) actively participated for the development of CALL in English Language Teachings Reforms (ELTR), so that the teachers could be properly trained and may be able to use the technology of CALL for English language teaching purposes.

\section{Research Methodology}

\subsection{Methodological Framework}

The current research study followed a quantitative approach and the tool which was used for the collection of date is close-ended questions. Research design was descriptive and survey method was used to gather data from the selected respondents.

\subsection{Participants}

The sample determined for this study was 300 students. They were divided into equally proportional groups i.e. 150 males ( 75 from private and 75 from government) and 150 females ( 75 from private and 75 from government). The sample was taken from Khanpur, Rahim Yar Khan and Sadiqabad tehsils of district Rahim Yar Khan. The participants were of 18 to 20 years. The sampling technique used for this study was random sampling. Random sampling means the method in which a researcher gives an equal and independent chance to every member of population being selected as a subject. The random sampling technique was used to fulfill the criteria of quantitative research paradigms by eliminating the chance of investigator effects and controlling the extraneous variables.

\subsection{Instrumentation}

The instrument which was employed in this study was questionnaire. The researchers developed and piloted the questionnaire before its administration. The data obtained from questionnaire was quantitative in nature, so 
closed ended statements were added in the instrument. The questionnaire was divided into three sections with subsidiary statements. Five point likert scale (Strongly Agree, Agree, Strongly disagree, Disagree and Neutral) was used to gather students' responses. After the development of questionnaire pilot study was conducted to check the accuracy and feasibility of tool. The validity and reliability factors were ensured before finalizing the tool prior to its administration.

\section{Data Analysis}

Table 1. Attitude towards computers

\begin{tabular}{llllllll}
\hline Statement & Respondents & SA & A & DA & SDA & N & Mean Score \\
\hline I generally have positive & Govt. (Male) & 27 & 39 & 1 & 2 & 6 & 4.17 \\
attitudes towards using & Govt. (Female) & 20 & 44 & 3 & 1 & 7 & 4.05 \\
computers in language & Total Govt. & 47 & 83 & 4 & 3 & 13 & 4.11 \\
instruction. & & 44 & 19 & 5 & 0 & 7 & 4.36 \\
& Private (Male) & 16 & 24 & 8 & 5 & 22 & 3.51 \\
& Private (Female) & 60 & 43 & 13 & 5 & 29 & 3.94 \\
\hline
\end{tabular}

Coding: (Strongly Agree SA: 5, Agree A: 4, Neutral N: 3, Disagree DA: 2, Strongly Disagree SDA: 1).

Table 1 provides the statistical description of government and private (male and female) students' positivity towards the usage of computer for language instruction. Out of 150 government students, mean value 4.17 of govt. males showed more positivity than 4.05 mean of govt. female students; and out of 150 private students mean 4.36 of private males showed more positivity than 3.51 mean of private females. It indicates that the male participants have more positive attitude towards computer than female participants. If we compare the mean score of govt. males with the mean score of private males, the private males (4.36) are in lead than Govt. males (4.17) and on the contrary govt. females (4.05) are in lead than private females mean value (3.51). Overall data shows that govt. students showed more positivity towards the usage of computer in language instruction than private students.

Table 2. Contribution of computers

\begin{tabular}{llllllll}
\hline Statement & Respondents & SA & A & DA & SDA & N & Mean Score \\
\hline Using computers generally & Govt. (Male) & 31 & 34 & 3 & 3 & 4 & 4.16 \\
makes completing tasks & Govt. (Female) & 30 & 17 & 3 & 2 & 23 & 3.93 \\
easier. & Total Govt. & 61 & 51 & 6 & 5 & 27 & 4.05 \\
& Private (Male) & 44 & 22 & 1 & 0 & 8 & 4.45 \\
& Private (Female) & 29 & 27 & 6 & 6 & 7 & 3.89 \\
& Total Private & 73 & 49 & 7 & 6 & 15 & 4.17 \\
\hline
\end{tabular}

Coding: (Strongly Agree SA: 5, Agree A: 4, Neutral N: 3, Disagree DA: 2, Strongly Disagree SDA: 1).

Table 2 shows the statistical mean scores of government and private male and female students towards computers contribution in the completion of tasks. Out of 300 students, Govt. males with mean 4.16 and private males with mean 4.43 show more positive attitudes towards computers role in making the task easier than Govt. and private female students. But the total 4.17 statistical mean of private students shows more lead regarding computer's help in task completion than the 4.05 mean of government students. 
Table 3. Computers and AVAs

\begin{tabular}{|c|c|c|c|c|c|c|c|}
\hline Statement & Respondents & SA & $\mathrm{A}$ & $\mathrm{DA}$ & SDA & $\mathrm{N}$ & Mean Score \\
\hline \multirow{6}{*}{$\begin{array}{l}\text { CALL provides audio } \\
\text { visual learning opportunity } \\
\text { to the students. }\end{array}$} & Govt. (Male) & 35 & 30 & 3 & 1 & 6 & 4.27 \\
\hline & Govt. (Female) & 14 & 47 & 1 & 5 & 8 & 3.85 \\
\hline & Total Govt. & 49 & 77 & 4 & 6 & 14 & 4.06 \\
\hline & Private (Male) & 20 & 45 & 2 & 2 & 6 & 4.05 \\
\hline & Private (Female) & 14 & 35 & 11 & 7 & 8 & 3.51 \\
\hline & Total Private & 34 & 80 & 13 & 9 & 14 & 3.78 \\
\hline
\end{tabular}

Coding: (Strongly Agree SA: 5, Agree A: 4, Neutral N: 3, Disagree DA: 2, Strongly Disagree SDA: 1).

Audio visual aids facilitate language learning and teaching process. Table 3 shows the statistical description of private and government students' belief towards the statement that CALL contributes in the opportunity of learning through audio visual aids. Out of 300 students Govt. and private males support the statement more than Govt. and private females. The total statistical mean of government students is 4.06 and of private students is 3.51. So, the data shows that the government students are in more support of the statement as compared to private students.

Table 4. Integration of CALL at intermediate level

\begin{tabular}{llllllll}
\hline Statement & Respondents & SA & A & DA & SDA & N & Mean Score \\
\hline $\begin{array}{l}\text { CALL technology should } \\
\text { be provided to all students }\end{array}$ & Govt. (Male) & 40 & 27 & 1 & 3 & 4 & 4.34 \\
of intermediate levels in & Govt. (Female) & 54 & 4 & 15 & 1 & 1 & 4.27 \\
Pakistan. & Total Govt. & 94 & 31 & 6 & 4 & 5 & 4.31 \\
& Private (Male) & 25 & 40 & 2 & 0 & 8 & 4.17 \\
& Private (Female) & 34 & 20 & 5 & 11 & 5 & 3.81 \\
& Total Private & 59 & 60 & 7 & 11 & 13 & 3.99
\end{tabular}

Coding: (Strongly Agree SA: 5, Agree A: 4, Neutral N: 3, Disagree DA: 2, Strongly Disagree SDA: 1).

Table 4 indicates the statistical views of private and government students towards the statement that CALL should integrate with the learning process of intermediate students. Data describes that Govt. males showed more positivity than Govt. females although there is a bit difference in their attitudes; and out of 150 private students, majority of private males indicated more positivity than private females. However the government students' total mean 4.31 leads the favor than the 3.99 mean of the private students. On the whole, government students were more in favor of integrating CALL at intermediate level than private students.

Table 5. Language proficiency through CALL

\begin{tabular}{|c|c|c|c|c|c|c|c|}
\hline Statement & Respondents & SA & A & $\mathrm{DA}$ & SDA & $\mathrm{N}$ & Mean Score \\
\hline \multirow{6}{*}{$\begin{array}{l}\text { Language proficiency can } \\
\text { be increased through the } \\
\text { usage of computers. }\end{array}$} & Govt. (Male) & 33 & 34 & 2 & 1 & 5 & 4.28 \\
\hline & Govt. (Female) & 49 & 20 & 2 & 2 & 2 & 3.53 \\
\hline & Total Govt. & 82 & 54 & 4 & 3 & 7 & 3.90 \\
\hline & Private (Male) & 37 & 28 & 2 & 0 & 8 & 4.33 \\
\hline & Private (Female) & 22 & 28 & 9 & 6 & 10 & 4.05 \\
\hline & Total Private & 59 & 56 & 11 & 6 & 18 & 4.19 \\
\hline
\end{tabular}

Coding: (Strongly Agree SA: 5, Agree A: 4, Neutral N: 3, Disagree DA: 2, Strongly Disagree SDA: 1). 
Table 5 shows the statistical difference of private and government students in regard to use of computer for the enhancement of language proficiency. It is evident that government males showed more interest towards the statement that language proficiency can be increased through the usage of computers than their female counterparts; and 4.33 mean score of private males showed more interest than private females with mean score 4.05. The total mean indicates that private students (4.19) showed more positivity towards the statement than government students (3.90). Overall, majority of the students were strongly agree that there is positive correlation between English language proficiency and usage of CALL technology in language class.

Table 6. CALL and Textbook reading

\begin{tabular}{llllllll}
\hline Statement & Respondents & SA & A & DA & SDA & N & Mean Score \\
\hline I read English text fluently & Govt. (Male) & 33 & 28 & 3 & 1 & 10 & 4.19 \\
with the help of computer. & Govt. (Female) & 15 & 40 & 8 & 2 & 10 & 3.77 \\
& Total Govt. & 48 & 68 & 11 & 3 & 20 & 3.98 \\
& Private (Male) & 38 & 27 & 4 & 0 & 6 & 4.32 \\
& Private (Female) & 18 & 35 & 9 & 7 & 6 & 3.64 \\
& Total Private & 56 & 62 & 13 & 7 & 12 & 3.98 \\
\hline
\end{tabular}

Coding: (Strongly Agree SA: 5, Agree A: 4, Neutral N: 3, Disagree DA: 2, Strongly Disagree SDA: 1).

6 shows the statistical response of private and government students towards the role of computer in the fluent reading of English text. Out of 150 government students, 4.19 mean of male students showed more positivity towards the statement than 3.77 mean of female learners; similarly 4.32 mean value of private males showed more positivity than 3.64 mean calculations of private females. The total statistical values of both the government and private students are equal that is 3.98. It means both government and private sector students hold similar attitude regarding relationship of CALL with reading skills.

Table 7. CALL and memory development

\begin{tabular}{llllllll}
\hline Statement & Respondents & SA & A & DA & SDA & N & Mean Score \\
\hline I memories English phrases & Govt. (Male) & 31 & 30 & 6 & 2 & 6 & 4.09 \\
well through the use of & Govt. (Female) & 23 & 25 & 8 & 0 & 19 & 3.84 \\
computer. & Total Govt. & 54 & 55 & 14 & 2 & 25 & 3.97 \\
& Private (Male) & 35 & 28 & 3 & 1 & 8 & 4.24 \\
& Private (Female) & 16 & 24 & 12 & 6 & 17 & 3.52 \\
& Total Private & 51 & 52 & 15 & 7 & 25 & 3.88 \\
\hline
\end{tabular}

Coding: (Strongly Agree SA: 5, Agree A: 4, Neutral N: 3, Disagree DA: 2, Strongly Disagree SDA: 1).

Technology can help in providing concrete and valid learnable input to English language learners. Table 7 statistically shows the response of private and government students towards memory development through the usage of computers. Data shows that 4.09 mean of govt. males and 4.24 mean of private males show more positive attitude than 3.84 mean of govt. females and 3.52 mean of private female students. The total statistical mean of government students is 3.97 and mean score of private students is 3.88 .

Table 8. CALL and language comprehension

\begin{tabular}{llllllll}
\hline Statement & Respondents & SA & A & DA & SDA & N & Mean Score \\
\hline To understand unfamiliar & Govt. (Male) & 38 & 23 & 5 & 2 & 7 & 4.20 \\
words, I use the technology & Govt. (Female) & 27 & 34 & 5 & 5 & 4 & 3.97 \\
\hline
\end{tabular}




\begin{tabular}{llllllll}
\hline of computer for it. & Total Govt. & 65 & 57 & 10 & 7 & 11 & 4.09 \\
& Private (Male) & 33 & 29 & 1 & 2 & 10 & 4.20 \\
& Private (Female) & 33 & 23 & 8 & 4 & 7 & 3.97 \\
& Total Private & 66 & 52 & 9 & 6 & 17 & 4.09 \\
\hline
\end{tabular}

Coding: (Strongly Agree SA: 5, Agree A: 4, Neutral N: 3, Disagree DA: 2, Strongly Disagree SDA: 1).

Table 8 statistically shows the mean of private and government students towards the statement that computer contributes its important role in the understanding of new words and language comprehension. Out of 150 government students, 4.20 mean of govt. males showed more positivity than 3.97 mean of govt. females. Similarly, mean calculations 4.20 of private males showed more interest towards the statement than 3.97 mean of private females. The total mean of both the government and private students are equal that is 4.09 . It means majority of the students from both private and government sectors are strongly agree with the notion discussed above.

Table 9. Technology difficulties while using computers

\begin{tabular}{|c|c|c|c|c|c|c|c|}
\hline Statement & Respondents & SA & A & DA & SDA & $\mathrm{N}$ & Mean Score \\
\hline \multirow{6}{*}{$\begin{array}{l}\text { Computer operating is a } \\
\text { very difficult. }\end{array}$} & Govt. (Male) & 8 & 15 & 26 & 15 & 11 & 2.67 \\
\hline & Govt. (Female) & 33 & 38 & 2 & 0 & 2 & 4.36 \\
\hline & Total Govt. & 41 & 53 & 28 & 15 & 13 & 3.52 \\
\hline & Private (Male) & 9 & 12 & 26 & 21 & 7 & 2.49 \\
\hline & Private (Female) & 23 & 15 & 12 & 10 & 15 & 3.39 \\
\hline & Total Private & 32 & 27 & 38 & 31 & 22 & 2.94 \\
\hline
\end{tabular}

Coding: (Strongly Agree SA: 5, Agree A: 4, Neutral N: 3, Disagree DA: 2, Strongly Disagree SDA: 1).

Table 9 is the statistical interpretation of private and government students' perspective towards the difficulty faced while operating the computers. Government and private students indicate different statistical attitude in this regard. 3.39 mean of private females and 4.36 mean of govt. females indicated that they faced more difficulties while operating the computer technology than 2.67 mean of govt. males and 2.49 mean of private males. The total mean of government students is 3.52 and of private students is 2.94 . This indicated that the government students face more difficulties for the utilization of computer than private students.

Table 10. Cost effectiveness of technology

\begin{tabular}{llllllll}
\hline Statement & Respondents & SA & A & DA & SDA & N & Mean Score \\
\hline Computers are expensive. & Govt. (Male) & 28 & 28 & 9 & 2 & 8 & 3.95 \\
& Govt. (Female) & 55 & 13 & 4 & 2 & 1 & 4.53 \\
& Total Govt. & 83 & 41 & 13 & 4 & 9 & 4.24 \\
& Private (Male) & 12 & 26 & 22 & 10 & 5 & 3.11 \\
& Private (Female) & 16 & 22 & 12 & 5 & 20 & 3.43 \\
& Total Private & 28 & 48 & 34 & 15 & 25 & 3.27
\end{tabular}

Coding: (Strongly Agree SA: 5, Agree A: 4, Neutral N: 3, Disagree DA: 2, Strongly Disagree SDA: 1).

Table 10 shows the statistical interpretation of private and government students' attitude towards the statement that computers are not affordable for the learners. Out of 300 students, 4.53 mean of govt. females are more expressive towards the statement than 3.95 mean of govt. males, and 3.43 mean of private females are more expressive towards the fact that computers are expensive than 3.11 mean of private males. The total mean of government is 4.24 and it indicates that government students are more agreed that computers are expensive than 
the 3.27 mean of private students. Data reflects that computer and CALL technology is affordable for the private sector students than the students belong to the government sector.

Table 11. Teachers' competency related to CALL

\begin{tabular}{|c|c|c|c|c|c|c|c|}
\hline Statement & Respondents & SA & $\bar{A}$ & DA & SDA & $\mathrm{N}$ & Mean Score \\
\hline \multirow{6}{*}{$\begin{array}{l}\text { Teachers are } \\
\text { professionally trained in } \\
\text { computer operating. }\end{array}$} & Govt. (Male) & 22 & 25 & 10 & 1 & 17 & 3.47 \\
\hline & Govt. (Female) & 57 & 15 & 2 & 1 & 0 & 4.67 \\
\hline & Total Govt. & 79 & 40 & 12 & 2 & 17 & 4.07 \\
\hline & Private (Male) & 17 & 25 & 7 & 8 & 18 & 3.48 \\
\hline & Private (Female) & 40 & 20 & 5 & 3 & 7 & 4.19 \\
\hline & Total Private & 57 & 45 & 12 & 11 & 25 & 3.84 \\
\hline
\end{tabular}

Coding: (Strongly Agree SA: 5, Agree A: 4, Neutral N: 3, Disagree DA: 2, Strongly Disagree SDA: 1).

It is also compulsory that English teachers should be well acquainted and equipped with computer technology and internet. Table 11 is the statistical information of private and government students' views towards the statement that training is not provided to the teachers for professional use of computer. Data shows that 4.67 mean of govt. females and 4.19 mean of private females are more expressive towards the statement than 3.47 mean of govt. males and 3.48 mean of private male learners. The total statistical mean of government is 4.07 and of private sector is 3.84 . The total mean of government indicates that government students are more agreed that their teachers are not professionally trained for the operating of computers than the teachers of private institutions.

Table 12. Technology threats

\begin{tabular}{llllllll}
\hline Statement & Respondents & SA & A & DA & SDA & N & Mean Score \\
\hline Technology intimidates and & Govt. (Male) & 9 & 17 & 18 & 10 & 21 & 2.96 \\
threatens me. & Govt. (Female) & 18 & 30 & 10 & 11 & 6 & 3.45 \\
& Total Govt. & 27 & 47 & 28 & 21 & 27 & 3.20 \\
& Private (Male) & 11 & 11 & 20 & 29 & 4 & 2.40 \\
& Private (Female) & 11 & 22 & 14 & 12 & 16 & 3.08 \\
& Total Private & 22 & 33 & 34 & 41 & 20 & 2.74 \\
\hline
\end{tabular}

Coding: (Strongly Agree SA: 5, Agree A: 4, Neutral N: 3, Disagree DA: 2, Strongly Disagree SDA: 1).

Table 12 is the statistical interpretation of private and government students' views towards the statement that the students become frightened by the utilization of technology. Out of 300 students 3.45 mean of govt. females and 3.08 mean of private females show significantly stronger views towards this phenomenon than 2.96 mean of govt. males and 2.40 mean of private males. The total 3.20 mean indicates that the government students are more frightened than their private sector counterparts regarding experiencing technology threat while learning English.

\section{Findings and Discussions}

The main objective of the researchers was to find out the attitude of the students towards the computer assisted language learning (CALL). So according to it the questionnaire was designed. The first part of the tool was about to examine the attitude of the male and female students. Male participants showed more positive attitude towards the statement as compared to female participants. The element of gender also specifies the individuals' attitude towards the tools of technology. The male learners as compared to female learners have an appreciative attitude towards technology (Kalanda, 2005). Computer related technologies boost the students to upgrade their communicative skills in second language and also play the role of tutor to instruct and guide language learners. This widely accepted claim has been endorsed by Hubbard (2005) and Fisher (2007) that the computer technology functions in two different ways: as a tool and as a tutor. Through the second section of the 
questionnaire, the researchers had to check the responses of the intermediate students in order to examine the functionality of CALL in the development of language proficiency. Findings reveal that, as compared to female participants, male participants found computer assisted language learning (CALL) more interesting and facilitating for the development of language proficiency. Janada (2009) expressed his point that the students who utilize the computers for their work, they take more interest in it and want to pass their valuable time in the computer labs as compared to classrooms.

In the last part of the questionnaire the researchers had to examine the difficulties that students faced while operating the computer technology. In this section female participants are more expressive towards the statements which are generally about the computer handling, computer expensiveness and most importantly teachers lack of professionalism in the operating of computers. Mumtaz (2000) stated that majority of teachers want to utilize the technology of computer but the main drawback is that most of the teachers are unaware with the technology of computer and they don't know how to use it appropriately. The training of the teachers is very important because it will lead to the effective learning of the students and also in order to the change of teaching methodology the development of professionalism in the use of computers must be focused ( $\mathrm{Li}$ and Protacio, 2010; Shi and Bichelmeyer, 2007; Wei, Darling-Hammond, Andree, Richaerdson, and Orphanos, 2009). According to Gips \& Dimattia (2004), if computer technology becomes a necessary tool for the purpose of language learning than it will expand the fees for the students. He further stated that it is difficult for the poor students to manage the computers for the study and learning purposes. The current study also concluded that students who belong to government institutions face much difficulty in purchasing computer and internet technology for language learning purposes.

\section{Conclusion}

Today we are living in the digital world where technology is the main focus in attaining and retaining academic and professional success. The practical usage of technology leads us to the domain of success and enables us to stand with the globalized world. CALL (computer assisted language learning) is one of the approach that functions as a tool and tutor in the language learning domain. It contributes its role in the enhancement of language proficiency as it includes a variety of activities for the improvement of four major skills (listening, writing, reading and speaking). CALL approach increases the interest of the teachers, learners and research scholars and it contributes its important role in the process of language learning and teaching (Hubbard, 2005). CALL provides many applications and software of improving vocabulary, grammar, pronunciation, accent, writing boards and reading skills. CALL also assists the teachers to improve their teaching skills and linguistic abilities. It involves many interesting activities that attract the attention of the learners and make language learning phenomenon an interesting and autonomous process.

The findings of the research work can be concluded as majority of the male students have more positive attitude towards the computer assisted language learning (CALL) as compared to female learners. Secondly, male participants find CALL more functional for the development of language proficiency as compared to female respondents. It is also found that female students comparatively faced more difficulties while using computer technology for language learning purposes.

The findings of the current study are in liaison with the revelations of many previous researches. CALL brought revolutionary change for the students because in traditional and old method classrooms, the role of the students is just simply to listen, follow the instructions of teachers and answer the teachers' questions (Sandlots et. al., 1990). Metz (as cited in Muir-Herzig, 2003) gives the name to these types of classrooms as "real classrooms". It has been long recognized that the traditional classrooms are not fruitful for enhancing the learning skills of students. These types of classroom suppressed the abilities, skills and creativity of students. If classrooms don't reflect real life situations then it will be difficult for the students to communicate in real life and situations (Sandholtz et al., as cited in Muir- Herzig, 2003). The use of CALL as a main tool in classrooms opens many ways for the students because it provides audio-visual and communicative approaches.

The current study also recommends the need of further research works in the area of computer assisted language learning. The prospective researchers should conduct other studies related to CALL in order to measure the attitude and the perspectives of the English teachers. It is further recommended that more work needs to be done to investigate the role and impact of CALL in enhancing individual English proficiency skills of learners at different levels of education. Furthermore, government should arrange teachers training workshops on CALL to develop and enhance pedagogical skills of English language teachers. 


\section{References}

Abdullah, N. M. (2005). The effectiveness of a suggested unit of the instructional technology requirements necessary for the English language teacher's training. Unpublished thesis, Halway University, Cairo, Egypt.

Al-Hajailan, T. (2003). Teaching English in Saudi Arabia. Riyadh KSA: Aldar Alsawlatiah.

Fisher, R. (2007). How do we know what students are actually doing? Monitoring students' behavior in CALL. Computer Assisted Language Learning, 20(5), 409-442. https://doi.org/10.1080/09588220701746013

Gips, A., DiMattia, P., \& Gips, J. (2004). The effect of assistive technology on educational costs: Two case studies. In K. Miesenberger, J. Klaus , W. Zagler, \& D. Burger (Eds.), Test validity (pp. 77-86). Hillsdale, NJ: Lawrence Erlbaum.

Hacken, P. T. (2003). Computer-assisted language learning and the revolution in computational linguistics. Retrieved December 3, 2018, from http://www.linguistik-online.de/17_03/

Higgins \& Chris. (1993). Computer-assisted language learning: Current programs and projects. ERIC Digest. Retrieved December 3, 2009, from http:/www.ericdigests.org/1993/language.html

Hubbard, P. (2005). A review of subject characteristics in call research. Computer Assisted Language Learning, 18(5), 351-368. https://doi.org/10.1080/09588220500442632

Jaber, W. E. (1997). A survey of factors which influence teachers' use of computer based technology. Retrieved from http://www.scholar.lib.vt.edu/theses/available/etd-7199702347/unrestricted/WJABER2.PDF

Janada, R. (2009). CALL-Based Instruction: Toward the Teaching of Speech and Oral Communication at Angeles University Foundation. Asian EFL Journal, 11(5).

Javid, Z. C., \& Farooq, U. M. (2015). Experimenting in-house EMP course contents for Saudi medical undergraduates: Lessons learned. Journal of Critical Inquiry, 13(I), 38-57.

Kalanda, K. (2005). Factors influencing college students' attitude towards technology. (Unpublished Master's dissertation, University of South Africa). Retrieved from http://uir. unisa.ac.za/bitstream /handle/10500 $/ 1531 /$ dissertation. pdf?sequence $=1$

Kronstadt, A. K. (2004). Education reform in Pakistan. CRS Report for Congress. Received through the CRS Web Order Code RS22009. Retrieved February 13, 2018, from http://www.RS22009_pdf

Levy, M. (1997). Computer-assisted language learning: Context and conceptualization. Oxford: Oxford University Press. https://doi.org/10.1080/0958822970100103

Li, G., \& Protacio, M. S. (2010). Best practices in professional development for teachers of ELLs. In G. Li, \& P. Edwards (Eds.), Best practices in ELL instruction. NY: Guilford Press.

Ministry of Education. (1992). National education policy. Retrieved, June 3, 2018, from http://thejournal.com/Articles/1997/01/01/InternationalActivities.aspx

Ministry of Education. (1998-2010). National education policy. Government of Pakistan, Islamabad.

Mishra, S., \& Sharma, R. C. (2005). Interactive multimedia in educating and training. Hershey, PA: Idea Group Inc. https://doi.org/10.4018/978-1-59140-393-7

Muir-Herzig, R. G. (2003). Technology and its impact in classroom. Computers and Education, 42(2), $111-131$. https://doi.org/10.1016/S0360-1315(03)00067-8

Mumtaz, S. (2000). Factors Affecting Teachers' Use of Information and Communications Technology: A review of the Literature. Journal of Information Technology for Teacher Education. https://doi.org/10.10 $80 / 14759390000200096$

Sandholtz, J. D., Ringstaff, C., \& Dwyer, D. C. (1990). Teaching in high-tech environments: Classroom management revisited. Retrieved from http:// www.apple.com/education/k12/leadership/acot/pdf/rpt10.pdf

Schütz, R. (2005). English-The international language. Retrieved January 20, 2018, from http://www.sk. com.br/sk-ingl.html

Shi, M., \& Bichelmeyer, B. A. (2007). Teachers' experiences with computers: A comparative study. Educational Technology and Society, 10(2), 180-190.

Vincent, E., \& Hah, M. (1996). Strategies employed by users of a Japanese computer assisted language learning (CALL) program. https://doi.org/10.14742/ajet.2033 
Vrasidas, C., Georgeous, A. S., \& Papanastasiou, E. (2007). Educational media and innovative practice: Challenges and visions. Proceedings of September 2007conference on innovative learning environment Nicosia, Cyprus: International Council for Educational Media.

Wei, R. C., Darling-Hammond, L., Andree, A., Richardson, N., \& Orphanos, S. (2009). Professional learning in the learning profession: A status report on teacher development in the United States and abroad. Dallas, TX: National Staff Development Council.

\section{Copyrights}

Copyright for this article is retained by the author(s), with first publication rights granted to the journal.

This is an open-access article distributed under the terms and conditions of the Creative Commons Attribution license (http://creativecommons.org/licenses/by/4.0/). 